\title{
The efficiency of irrigation methods for soybean and corn cultivation
}

\author{
1. Ovchatov \\ State Enterprise Experimental farm "Velyki Klyny» of the Institute of Water Problems and Land \\ Reclamation of NAAS \\ 7 Konotopa Str., Velykyi Klyn vill., Holoprystan district, Kherson oblast, 75635, Ukraine \\ e-mail: igor.acpekt@ukr.net \\ ORCID: 0000-0002-0912-1365
}

Goal. To make an assessment and to determine the effectiveness of different irrigation methods for growing soybeans and corn, which are based on economic and energy parameters. Methods. Short-term field experiment, analytical and statistical methods of experimental data processing. Results. It is confirmed that the use of irrigation in crop production is a highly effective measure of its intensification and provides high economic and energy parameters. Thus, at growing soybeans and corn the highest conditional net profit was received for drip irrigation -37.88 and 73.85 thousand $\mathrm{UAH} / \mathrm{ha}$. The level of profitability made 59.5 and $94.2 \%$, and the lowest cost of production made 10.85 and 3, 78 thousand UAH/t respectively. Economic indicators for subsoil drip irrigation and sprinkling were close in values: conditional net income of soybeans -19.45 and 18.07 thousand $\mathrm{UAH} / \mathrm{ha}$, corn -53.65 and 54.51 thousand $\mathrm{UAH} / \mathrm{ha}$, the level of profitability 37,3 and $36.3 \%$ and 80.2 and $88.7 \%$, the cost of production -12.60 and 12.69 thousand $\mathrm{UAH} / \mathrm{t}$ and 4.07 and 3.88 thousand $\mathrm{UAH} / \mathrm{t}$ for growing soybeans and corn, respectively. Irrigation increased the energy intensity of soybean and corn cultivation technology by 2.8 and 2.1 times - to 59.6 and $79.6 \mathrm{GJ} / \mathrm{ha}$ and 109.2 and $117.5 \mathrm{GJ} / \mathrm{ha}$, respectively. Without irrigation, the costs of soybean production were in the range of 23.6 GJ/ha, corn - 53.6 GJ/ha. Conclusions. The maximum efficiency of soybean and corn cultivation was at the use of drip irrigation. The lower and close in values indicators of economic and energy efficiency of cultivation were fixed for the conditions of subsoil drip irrigation and sprinkling. The lowest efficiency of soybean and corn cultivation was obtained in the conditions of natural moisture, which confirms the significant risks and inexpediency of growing these crops in the Steppe without additional artificial moisture.

Key words: sprinkling, drip irrigation, subsoil drip irrigation, economic parameters, energy assessment.

DOI: https://doi.org/10.31073/agrovisnyk202012-10

Over the past 10-15 years, agricultural production in Ukraine has reoriented to growing the most profitable and highly liquid crops, in particular soybeans and corn, the sown area under which in 2020 amounted to $1,340,000$ hectares and 5,450,000 hectares, respectively [1]. It is natural that a high level of productivity when growing these crops, farmers get on irrigation [2]. So, the irrigated areas under soybeans and corn are from 130 to 175 thousand hectares annually [2], and the main method of irrigating these crops is sprinkling. Today, an alternative to sprinkling is a drip irrigation with surface and subsurface laying of irrigation pipelines (PT) at a depth of $20-30 \mathrm{~cm}$ [3]. The introduction of these irrigation systems potentially provides higher yields and lower unit costs of irrigation water [4].

An important aspect of the introduction of irrigation technologies is to obtain economic profit based on the preservation of the ecological sustainability of reclaimed agricultural landscapes. Therefore, in a market economy, it is the economic and energy analysis of agricultural technologies that is important, since it gives grounds to justify the options for growing agricultural crops in terms of their profitability and energy conservation.

The substantiation of the effectiveness of soybean irrigation methods is highlighted in the works of scientists from the USA [5, 6] and the Russian Federation [7]. Similar studies on corn crops were carried out by scientists from the Institute of Irrigated Agriculture of the NAAS [8], Kherson State Agrarian University [9] and the University of Kansas (USA) [10].

The difference between our studies lies in the analysis and substantiation of the effectiveness of three methods of irrigation: sprinkler irrigation, drip irrigation and subsoil drip irrigation in a short-term crop rotation "soybean - corn".

The aim of the research is to evaluate and establish the effectiveness of various irrigation methods for growing soybeans and maize based on economic and energy parameters.

Materials and methods of research. The research was conducted on the lands of Kam'yanskoDniprovska research station IWPaLR NAAS in 2018-2020. Three methods of irrigation were studied: sprinkling (hose-drum DM - IRTEK 43FBT / 120), drip irrigation and subsurface drip irrigation with pipelines at the depth of $25 \mathrm{~cm}$. Conditional control was the option without irrigation. The research was carried out according to the generally accepted methods: placement of plots - systematic, repetition - four times, area of accounting plots - $30 \mathrm{~m}^{2}$ [11, 12], maize hybrid - DKC 5276 (FAO 460), soybean variety - Oksana. Irrigation source - a well with water salinity from 0,76 to $1.14 \mathrm{~g} / \mathrm{dm}^{3}$ (quality class II according to DSTU 2730, DSTU 
7286, DSTU 7591). The cost of supplying $1 \mathrm{~m}^{3}$ of water for irrigation was UAH 1,05. The soil of the experimental site is ordinary medium loam chernozem, the density of formation is $1,35-1,50 \mathrm{t} / \mathrm{m}^{3}$, the root layer is $18,8 \%$, the reaction of the soil solution is close to neutral. The level of pre-irrigation humidity, which was maintained in the experiment - $80 \%$ of $\mathrm{MMHC}$, calculation of irrigation norms and control of moisture reserves - in accordance with the recommendations [13]. The economic efficiency of irrigation methods was calculated on the basis of the accepted standards, norms and prices [14] of the current year, energy efficiency - according to the method of energy assessment of technologies for growing crops [15]. Depreciation period of units and parts of irrigation systems (except for the one-year period of use of the drip irrigation system) is 10 years.

Research results and their discussion. The calculation of the main economic parameters showed that at 2020 prices, the positive profitability of growing soybeans on drip irrigation is provided with a yield of 3,68 $\mathrm{t} / \mathrm{ha}$, on subsurface irrigation - from 3,02 t/ha, on sprinkling - from 2,88 t/ha and without irrigation - not less than $1,31 \mathrm{t} / \mathrm{ha}$. The positive profitability of growing corn on drip irrigation is provided with a yield of $10,66 \mathrm{t} / \mathrm{ha}$, with subsoil irrigation - from 9,12 t/ha, by sprinkling - from 8,38 t/ha and without irrigation - at least 3,36 t/ha (Table 1).

1. The main economic indicators of soybean and corn cultivation depending on irrigation methods

\begin{tabular}{|c|c|c|c|c|c|c|c|c|c|}
\hline \multirow[b]{2}{*}{$\begin{array}{l}\text { Irrigation } \\
\text { method }\end{array}$} & \multicolumn{4}{|c|}{ Costs, thousand UAH/ha, per: } & \multirow[b]{2}{*}{ 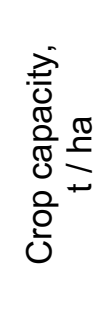 } & \multirow[b]{2}{*}{ 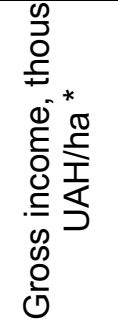 } & \multirow[b]{2}{*}{ 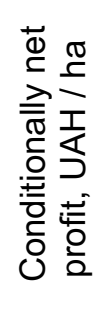 } & \multirow[b]{2}{*}{ 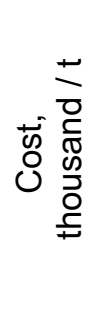 } & \multirow[b]{2}{*}{ 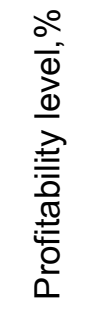 } \\
\hline & 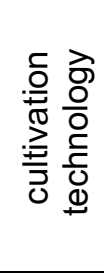 & 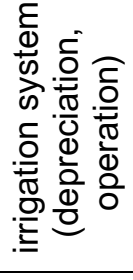 & 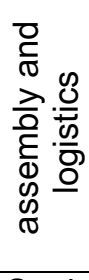 & 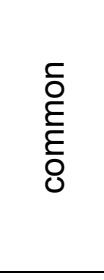 & & & & & \\
\hline \multicolumn{10}{|c|}{ Soybeans } \\
\hline Drip irrigation & 41,20 & 20,79 & 1,68 & 63,67 & 5,87 & 101,55 & 37,88 & 10,85 & 59,5 \\
\hline Subsurface drip irrigation & 39,05 & 11,94 & 1,18 & 52,17 & 4,14 & 71,62 & 19,45 & 12,60 & 37,3 \\
\hline Sprinkling & 37,24 & 11,39 & 1,12 & 49,75 & 3,92 & 67,82 & 18,07 & 12,69 & 36,3 \\
\hline Without irrigation & 22,10 & - & 0,52 & 22,62 & 1,38 & 23,87 & 1,25 & 16,39 & 5,5 \\
\hline \multicolumn{10}{|c|}{ Corn } \\
\hline Drip irrigation & 53,85 & 18,38 & 5,88 & 78,11 & 20,69 & 151,66 & 73,55 & 3,78 & 94,2 \\
\hline Subsurface drip irrigation & 50,81 & 11,36 & 4,69 & 66,86 & 16,44 & 120,51 & 53,65 & 4,07 & 80,2 \\
\hline Sprinkling & 46,09 & 10,85 & 4,51 & 61,45 & 15,82 & 115,96 & 54,51 & 3,88 & 88,7 \\
\hline Without irrigation & 23,52 & - & 1,10 & 24,62 & 3,85 & 28,22 & 3,60 & 6,39 & 14,6 \\
\hline
\end{tabular}

*In the calculations, the selling price of soybeans was taken as 17,30 thous./t, corn $-7,33$ thous./t. (as of November 16, 2020).

The most costly irrigation technology for both soybeans and corn is drip irrigation: annual operating costs, including depreciation deductions, are 20,79 and 18,38 thous./ha, respectively. At the same time, we note that with this irrigation method the highest yield was obtained $(5.87 \mathrm{t} /$ ha of soybeans and $20.69 \mathrm{t} / \mathrm{ha}$ of corn), which ensured the highest gross income and conditionally net profit per hectare, the maximum level of profitability and the lowest cost price grains.

The main economic indicators of soybean and corn cultivation under subsurface drip irrigation and sprinkling were close in values. Thus, with subsurface drip irrigation, a slightly higher level of yield was obtained $(+0,22 \mathrm{t} / \mathrm{ha}$ for soybeans and $+0,62$ t/ha for corn), however, the costs of implementing the technology were $4,9 \%$ higher than for sprinkling (soybeans) and 8,8\% (corn).

The lowest economic indicators and the highest cost of production were obtained in the conditions of natural moisture, which convincingly testifies to the significant risks and inexpediency of growing these crops in the Steppe without additional artificial moisture.

Along with the methods of assessing the efficiency of crop production through cost indicators, it is important to use a universal energy parameter - the coefficient of energy efficiency (table 2).

\section{Energy assessment of soybean and corn cultivation depending on irrigation methods}

\begin{tabular}{|l|c|c|c|}
\hline $\begin{array}{c}\text { Irrigation } \\
\text { method }\end{array}$ & $\begin{array}{c}\text { Energy input } \\
\text { with harvest, GJ / } \\
\text { ha }\end{array}$ & $\begin{array}{c}\text { Energy } \\
\text { consumption for } \\
\text { cultivation, GJ / } \\
\text { ha }\end{array}$ & $\begin{array}{c}\text { Energy efficiency } \\
\text { factor Ke }\end{array}$ \\
\hline Srip irrigation & 93,7 & 79,6 & 1,18 \\
\hline Subsurface drip irrigation & 66,1 & 62,2 & 1,06 \\
\hline Sprinkling & 62,6 & 59,6 & 1,05 \\
\hline
\end{tabular}




\begin{tabular}{|l|c|c|c|}
\hline Without irrigation & 22,0 & 23,6 & 0,93 \\
\hline Drip irrigation & 275,2 & 117,5 & 2,34 \\
\hline Subsurface drip irrigation & 218,7 & 112,9 & 1,94 \\
\hline Sprinkling & 210,4 & 109,2 & 1,93 \\
\hline Without irrigation & 51,2 & 53,6 & 0,96 \\
\hline
\end{tabular}

The analysis shows that irrigation increased the energy intensity of soybean and corn cultivation technology by 2,8-2,1 times - up to 59,6-79,6 GJ/ha and 109,2-117,5 GJ/ha, respectively. Without irrigation, the costs of soybean production were in the range of $23,6 \mathrm{GJ} / \mathrm{ha}$, and corn $-53,6 \mathrm{GJ} / \mathrm{ha}$.

Analysis of the value of the energy efficiency ratio $(\mathrm{Ke})$ indicates an average level of energy efficiency of soybean cultivation under irrigation $(\mathrm{Ke}=1,05-1,18)$ and a low level of energy efficiency of the option without irrigation ( $\mathrm{Ke}=0,93)$. The cultivation of corn with drip irrigation $(\mathrm{Ke}=2,34)$ was highly efficient and low efficient $(K e=0,96)$ without irrigation. With subsurface drip irrigation and sprinkler irrigation, the level of energy efficiency of corn cultivation was determined as average ( $K e=1694-1693$, respectively).

\section{Conclusions}

Drip irrigation provides maximum economic and energy efficiency of growing both soybeans and corn. Significantly lower and similar in values indicators of economic and energy efficiency of cultivation were determined for the conditions of subsurface drip irrigation and sprinkling. The lowest efficiency of soybean and corn cultivation was obtained in conditions of natural moisture, which confirms the significant risks and inexpediency of growing these crops in the Steppe without additional artificial moisture.

\section{References}

1. Posivni ploshchi silskohospodarskykh kultur za yikh vydamy u 2020 rotsi [Sown areas of agricultural crops by their types in 2020]. Derzhavna sluzhba statystyky Ukrainy. ukrstat.gov.ua. Retrieved from: http://www.ukrstat.gov.ua/ [In Ukr.].

2. Fomichov, M.V. (2019). Zroshennia yak chynnyk pidvyshchennia efektyvnosti vyroshchuvannia silskohospodarskykh kultur v Ukraini [Irrigation as a factor in improving the efficiency of growing crops in Ukraine]. Economics and state, 4, 92-96. doi: 10.32702/2306-6806.2019.4.92 [In Ukr.].

3. Sydorenko, A., Makarenko, I., \& Mihalov, A. (2020). Pidzemne krapelne zroshennia. Tekhnichne zabezpechennia ta zastosuvannia [Underground drip irrigation. Technical support and application]. The latest technologies in agriculture: research and management, 26(40), 280-291. doi: 10.31473/23055987-2020-1-26(40)-26 [In Ukr.].

4. Dudka, V.V. (2013). Zernovi kultury na kraplynnomu zroshenni [Cereals on drip irrigation]. Offer, 3 - 4 $(213-214), 72-82$.

5. Odhiambo, L., \& Irmak, S. (2015). Relative Evaporative Losses and Water Balance in Subsurface Drip and Center Pivot-Irrigated Soybean Fields. Journal of Irrigation and Drainage Engineering, 141 (11), (enl.), 3-20. doi: 10.1061/(ASCE)IR.1943-4774.0000907

6. Balakai, H.T., \& Syletskyi, S.A. (2019). Urozhainost sortov soi pri polive dozhdevanyem i systemami kapelnogo oroshenia $v$ usloviah Rostovskoi oblasti [Productivity of soybean varieties with sprinkling and drip irrigation systems in the Rostov region]. Scientific journal of the Russian Research Institute of Melioration Problems, 3 (35), 80-97. doi: 10.31774/2222-1816-2019-3-80-97. [In Rus.].

7. Kokovikhin, S.V., \& Biliaieva, I.M. (2017). Produktyvnist ta ekonomichna efektyvnist vyroshchuvannia hibrydiv kukurudzy zalezhno vid sposobiv polyvu ta zakhystu roslyn v umovakh Pivdnia Ukrainy [Productivity and economic efficiency of growing maize hybrids depending on the methods of watering and plant protection in the South of Ukraine]. Scientific reports of NULES, 4 (168). doi: 10.31548/dopovidi2017.04.013 [In Ukr.].

8. Averchev, O.V., Ivaniv, M.O., \& Lavrynenko, Yu.O. (2020). Indeksy vrozhainosti ta efektyvnoi produktyvnosti u hibrydiv kukurudzy riznykh hrup FAO za riznykh sposobiv polyvu ta volohozabezpechenosti $v$ posushlyvomu Stepu Ukrainy [Indices of yield and effective productivity of maize hybrids of different FAO groups under different methods of irrigation and moisture supply in the arid Steppe of Ukraine]. Tavriya scientific bulletin, 114, 3-13. doi: 10.32851/2226-0099.2020.114.1 [In Ukr.].

9. O'Brien, D.M., Rogers, D.H., Lamm, F.R., \& Clark, G. A. (1998). An economic comparison of subsurface drip and center pivot sprinkler irrigation systems. Applied engineering in agriculture, 14(4), (enl.), 391398. doi: $10.13031 / 2013.19401$.

10. Ushkarenko, V.O., Vozhehova, R.A., Holoborodko, S.P., \& Kokovikhin S.V. (2014). Metodyka polovoho doslidu (zroshuvane zemlerobstvo) [The methodology of field experiment: irrigation agriculture]. Kherson: Hrin D.S. [In Ukr.].

11. Romashchenko, M.I. (Ed.). (2014). Metodychni rekomendatsii z provedennia doslidzhen za kraplynnoho zroshennia [Methodical recommendations for conducting research under drip irrigation]. Kyiv: TOV DIA. [in Ukr.]. 
12. Romashchenko, M.I., Koriunenko, M.M., \& Muromtsev M.I. (2012). Rekomendatsii z operatyvnoho kontroliu ta upravlinnia rezhymom zroshennia silskohospodarskykh kultur iz zastosuvanniam tenziometrychnoho metodu [Recommendations for operational control and management of crop irrigation regime using tensiometric method]. Kyiv: Instytut vodnykh problem i melioratsii. [In Ukr.].

13. Zhuikov, H.le., \& Dymov, O.M. Normatyvy vytrat materialno-tekhnichnykh resursiv pry vyroshchuvanni osnovnykh zernovykh i tekhnichnykh kultur [Standards for the cost of material and technical resources in the cultivation of basic cereals and industrial crops]. Kherson: Ailant. [in Ukr.].

14. Enerhetychna otsinka systemy zemlerobstva i tekhnolohii vyroshchuvannia silskohospodarskykh kultur (metodychni rekomendatsii) [Energy assessment of the system of agriculture and technology of growing crops (guidelines)]. (2001). Kyiv: Nora-Prynt.[In Ukr.]. 